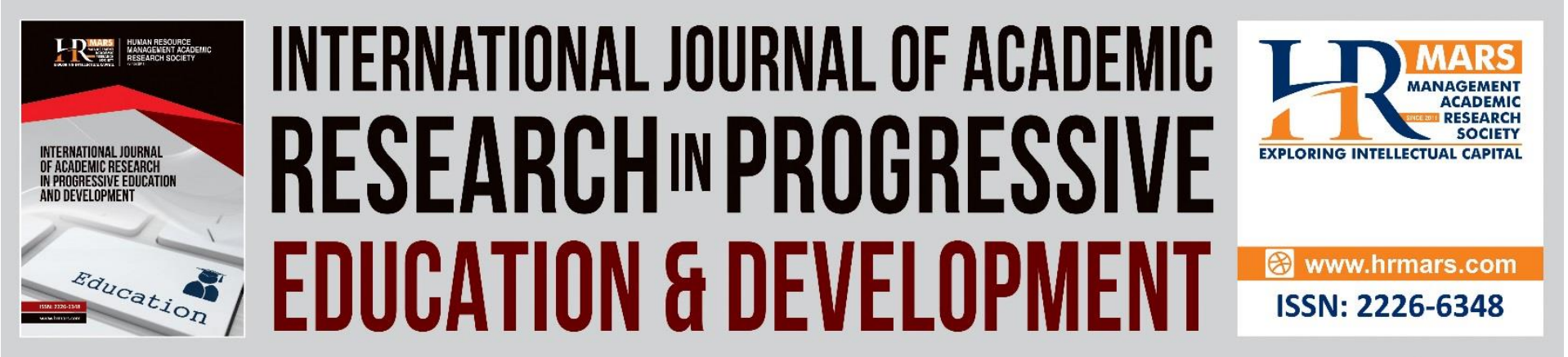

\title{
Leadership Competency of an Island School Principals in Sabah
}

Dexter Silam, Denis Lajium, Vincent Pang

To Link this Article: http://dx.doi.org/10.6007/IJARPED/v10-i4/11690

DOI:10.6007/IJARPED/v10-i4/11690

Received: 09 September 2021, Revised: 13 October 2021, Accepted: 28 October 2021

Published Online: 20 November 2021

In-Text Citation: (Silam et al., 2021)

To Cite this Article: Silam, D., Lajium, D., \& Pang, V. (2021). Leadership Competency of an Island School Principals in Sabah. International Journal of Academic Research in Progressive Education and Development, 10(4), 218-236.

Copyright: (C) 2021 The Author(s)

Published by Human Resource Management Academic Research Society (www.hrmars.com)

This article is published under the Creative Commons Attribution (CC BY 4.0) license. Anyone may reproduce, distribute, translate and create derivative works of this article (for both commercial and non-commercial purposes), subject to full attribution to the original publication and authors. The full terms of this license may be seen

at: http://creativecommons.org/licences/by/4.0/legalcode

Vol. 10(4) 2021, Pg. $218-236$

Full Terms \& Conditions of access and use can be found at http://hrmars.com/index.php/pages/detail/publication-ethics 


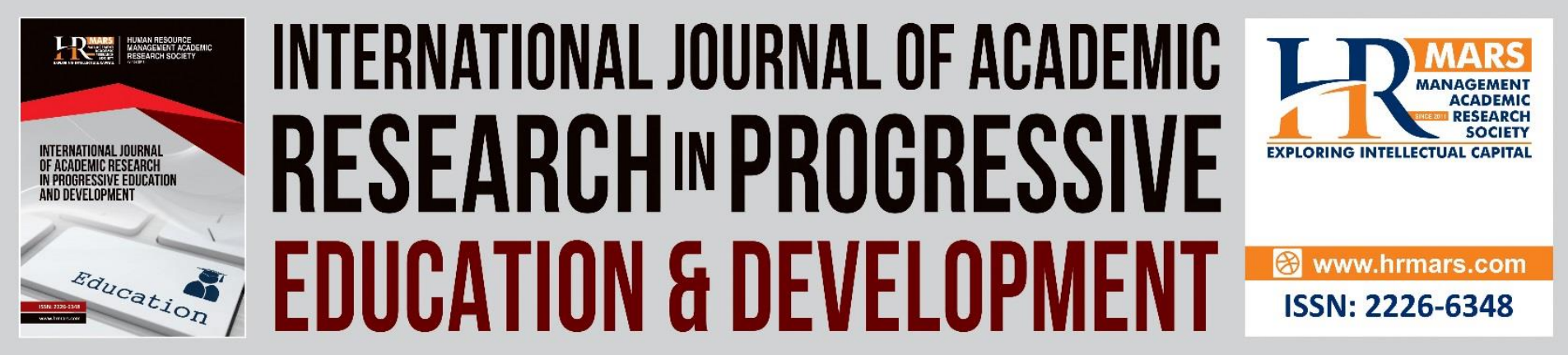

\title{
Leadership Competency of an Island School Principals in Sabah
}

\author{
Dexter Silam, Denis Lajium, Vincent Pang \\ Faculty Psychology and Education, University Malaysia Sabah \\ Email: dextersilam78@gmail.com
}

\begin{abstract}
The capability in managing school effectively and efficiently among school principals is always concern in education management. This study aims to identify the leadership competency and implementation practices of a principal of a school in a Sabah island. This qualitative study uses the case study approach. The respondents for this research are principals, administrative senior assistant and teachers. Data collection processes consist of interview, observation and document analysis. The data is processed and analysed using ATLAS.ti 8 software. The findings show that the principal of this island school need to possess leadership competencies in terms of knowledge, skills and behaviour in performing his duty efficiently and effectively, whether focusing on leading the school, teacher teaching, or operational aspects. In short, the leadership competencies of the school principal are very important in ensuring that the management and leadership of the school is always well-planned and systematic, and able to keep up with the current changes in the context of global education.

Keywords: Leadership Competencies, Island Principals, Island Schools, Qualitative Study, Management and Leadership

\section{Introduction}

The world of education is constantly changing in line with the passage of time and global demands. Therefore, the education system needs a leader of calibre in achieving the dreams and vision of the country. In educational institutions, the role of the principal is very important where his leadership style can influence and advance the level of change and various reforms in the school towards continuous improvement of the school (Fullan, 2015). Changes made need to take into account leadership in the school. This is because, the leaders in the school are the leaders in the success of the changes made. Meanwhile, Bush (2007) explained that the principal will have a significant influence in determining a change to be made in the school. In this case the principal is an individual who plays an important role in the success of a change depending on the school leadership. This is evidenced by Fullan (2007) that the determinant of success in change in schools depends on the leadership of the principal.
\end{abstract}

Changes in the education system are not easy to implement as they need to be carefully planned in order to be acceptable and produce positive changes. The changes made must be 
relevant to current needs and acceptable and achievable. Thus, in facing the demands of current educational change, it demands the readiness of school leaders in terms of knowledge, skills and attitudes. This coincides with the leadership competencies outlined by Tubbs and Schulz (2006) which see value, behaviour and personality as important elements that a leader needs to possess. This leadership competency will be the backbone of principals especially school principals on the island to accept and realize positive changes towards school effectiveness. This is in line with the readiness of principals as agents of change in schools to ensure that excellence can be achieved continuously (Schein, 2004). Ibrahim et al (2015) explained that the concept of educational leadership is very complex and is defined in various perspectives according to the situation, environment and socio-cultural background of the world community. In Malaysia, the leadership of the principal is seen as the backbone of the excellence of a school, especially in ensuring that the goals of the national education philosophy can be realized.

Thus, this study was made to explore the leadership competencies of school principals on the island in accordance with the demands of educational change that is happening around the world. This drastic change is also felt in Malaysia and requires us to be prepared to meet current needs in terms of ideas, programs, methods, technologies, processes, and components of education (Ministry of Education Malaysia, 2013).

\section{Objectives and Research Questions}

- $\quad$ This study aims to explore the competencies of school principals on the island in the state of Sabah. In addition, this study will also deepen the leadership competency needs of principals on the island to ensure that the management and leadership of schools on the island do not have a significant gap of differences with schools in the city.

The following are the research questions that will be answered in this study:

- What are the leadership competencies of school principals on the island in Sabah?

- To what extent is the need for the leadership competence of principals on the island to ensure that the management and leadership of schools on the island are not much different from schools in the city?

\section{Literature Review}

Leadership competence is not something new in the leadership of principals in schools. The leadership competencies of school principals are always emphasized as the main backbone in efforts to improve the effectiveness and efficiency of a school in accordance with the current challenges of very large and complex principals. Based on the Florida Department of Education (2008) definition, school principal leadership competencies begin with their knowledge of how to form an organization, establish collaboration with stakeholders and be able to respond and influence others. Hussein (1989) outlined several things that are often associated with principal competencies namely school mission, curriculum and teaching, school administration and relationships and communication. He stressed that, this competence is an important ingredient to make the school excellent. 
Competence is a characteristic required to do something (Bass \& Bass, 2008) and is a basic characteristic in an individual (Chen \& Naquin, 2006). These basic characteristics are needed by an individual to develop skills, knowledge, attitudes, beliefs, motives, and attributes towards quality work results in line with the demands of the organizational strategic function. A competent leader is an effective leader in implementing leadership for an organization (Bass \& Bass, 2008; Hollenbeck, McCall \& Silzer 2006; Rothwell, 2010). The competence of a leader needs to be identified because it is the main foundation that is the backbone to more effective management. Thus, competent leaders need to be appointed to lead the organization to ensure the excellence of an organization (Hollenback et al., 2006; Rothwell, 2010).

There are eight main areas of principals' competencies namely goal setting, program evaluation, staff management, time management, teaching and learning, ensuring the existence of teaching aids, professional development training and external relations with the community (Jokinen, 2005).

Meanwhile, the School Division (2004), Ministry of Education Malaysia has outlined the responsibilities of principals covering seven main areas namely teaching leadership, curriculum management, co-curriculum and student affairs, school management, finance, services and staffing, relationships with local communities and educational research. This is a competency that needs to be emphasized in a principal in leading the school organization.

The level of competence is seen as one of the main factors that catalyse the effectiveness of a school. This statement is supported by Eddy (2013) himself that in addition to the attitude of professional school leaders in addition to positive values in leadership, a high level of competence is also a factor in school effectiveness. Therefore, in line with that, the government through the Malaysian Education Development Plan (2013-2025) has taken the initiative by formulating proactive measures to increase the level of competence of school leaders. This is stated in the Malaysian Education Development Plan (2013-2025) through the implementation of Continuing Professional Development (CPD) training to school leaders involving senior assistants, field heads and committee heads. The question now is, is the government's intention stated above achieved to improve school and student achievement? This question is extended in this study in particular by looking at the development of education in island schools. Therefore, in this case, the leadership competencies of school principals on the island are considered as an important aspect that needs to be emphasized in ensuring the effectiveness of schools on the island, especially in the state of Sabah.

In this regard, school principals regardless of location must have efficient and effective leadership competencies in carrying out their responsibilities as the principal by focusing on school progress, teaching and learning in the classroom and matters related to student performance (Hallinger \& Murphy, 1985; Kotter, 1990; Katz, 1993; Leithwood et al., 2004; Interstate School Leaders Licensure Consortium, 2008).

In the face of a challenging mainstream, fast-paced and unrestricted world of principal leadership, principals are desperately required to equip themselves with diverse competencies (Institute Aminuddin Baki, 2005; Interstate School Leaders Licensure Consortium, 2008). Even school principals should more often increase efforts in mastering leadership competencies in line with the demands in changing the world of education, (Danim, 2002; Spencer \& Spencer, 1993). This should not be underestimated because according to 
DEVELOPMENT

Vol. 10, No. 4, 2021, E-ISSN: 2226-6348 @ 2021 HRMARS

Bennis and Nanus (1985) and supported by the findings of Drucker (1992) principals' leadership competencies are the main thrust that is the backbone to realize school goals.

Referring to the situation in Indonesia's neighbouring country, several previous reports indicate that the development of school principal competencies has not yet been implemented and practiced (Sudrajat, 2008; Renstra, 2009). In developed countries such as the United States and the United Kingdom, the issue of competency development of school principals is the main focus that needs to be considered to achieve excellence in education (Interstate School Leaders Licensure Consortium, 2008). In fact, Mazzeo (2003) mentioned that the developed countries have long made the strategy of enhancing the leadership competencies of principals as a system of licensed certificates that need to be renewed according to a set timeline. While in Malaysia, the construction and development of competencies of school principals is based on the program of building competencies of highperforming school principals through special leadership training and the National Principalship Professional Qualification Course (NPQEL) (Institute Aminuddin Baki, 2010).

Meanwhile, McNair et al (2011) asserted that an education leader should possess competencies and skills to enable them to manage the school effectively. In this case, the leadership competencies of a leader should be developed comprehensively and systematically in accordance with the demands of current educational change. Thus, in this case Eddy (2013) in his study explained that the development of competence of educational leaders can be made through several ways such as training, exploration of knowledge and experience gained during the period of service in an organization.

\section{Malaysian School Principals Competency Standards}

The Malaysian Education Quality Standard has been formulated by the Board of Inspectors and Quality Assurance which contains standard assurance instruments for school leaders to be complied with (School Board of Inspectors, 2004). This standard consists of four main dimensions, namely leadership direction, organizational management, educational program management and student development.

Based on the Department of Planning and Training Standards, IAB, Genting Highlands leadership competency standards in Malaysia are not much different from overseas competency standards (IAB, 2010). Significant differences only in terms of terms while in terms of content and scope of tasks still have similarities. Taking into account the views and results of joint discussions over a period of about two years from 2004 to 2006 between the IAB and the principal, officers of the District Education Office (PPD), State Education Department and Ministry of Education Malaysia (MOE) then the Malaysian School Principals Competency Standard (SKKSM) has been formed in 2006. In this SKKSM has been outlined nine areas of management in schools that need to be mastered by principals (IAB, 2006a). The nine aspects of educational leadership management should be mastered by the principal namely;

i. Organizational Management and Leadership

ii. Curriculum Management

iii. Co-Curriculum Management

iv. Student Affairs Management

v. Financial management 
DEVELOPMENT

Vol. 10 , No. 4, 2021, E-ISSN: 2226-6348 @ 2021 HRMARS
vi. Office Administration Management
vii. Environmental Management and Physical Facilities
viii. Human Resource Management and Development
ix. External Relations Management

Further, these nine aspects are actually components in NPQEL. NPQEL participants will be given exposure to SKKSM and become a participant syllabus for the first six months of NPQEL course implementation. Participants will be taught theoretically and they must pass the examination that has been set as a prerequisite to enable them to be appointed as future principals (IAB, 2006a). These aspects are also taught in the Leadership and Education Management Course (KKPP) for example in the preparatory course for new principals, namely the Immersion and Residency Program (PRIME) (IAB, 2006b). Even through short-term courses organized under the $I A B$, the emphasis on these nine competencies is also emphasized. However, the formulation of SKKSM is still based on the Principles of Rukun Negara, National Education Policy, National Education Philosophy and Vision 2020 (MOE, 2006). At the same time, IAB asserts that SKKSM is still guided by relevant theories and has relevance to educational management and leadership (IAB, 2006c). This is in line with the IAB's main function as an educational leadership training centre in Malaysia.

In this regard, the School Leaders Competency (KOMPAS) is also provided by IAB as one of the important instruments to identify the professional development needs of principals and head teachers based on 26 competencies known as School Leader Competencies. Based on a study conducted by $I A B$, there are six domains of competence that need to be mastered by school leaders included in KOMPAS (Senin, 2008). The main focus of KOMPAS developed is to identify the training and professional development needs of school leaders. Through KOMPAS, IAB has organized appropriate leadership training programs and according to the needs of school leaders. There are 100 items in the KOMPAS instrument that require leaders to respond honestly to each statement given within a period of 30 minutes. After that, leaders who have answered the KOMPAS instrument can save or print their competency profile slip (IAB, 2016). This aims to help leaders to plan school development plans as well as make analysis to obtain appropriate leadership courses under the management of IAB.

The IAB is also vulnerable to current changes in global educational demands. Therefore, IAB takes a smart and quick initiative so that school leaders are truly equipped with high leadership competencies and able to face any form of educational change that occurs. Therefore, IAB has introduced NPQEL 2.0 which outlines new guidelines and procedures for operating the NPQEL program. Based on the NPQEL 2.0 Assessment Handbook, IAB has introduced ten leadership competencies for principals and head teachers that must be mastered by NPQEL participants. The ten leadership competencies include strategic thinking, decision making, change leadership, leadership, problem solving, learning leadership, capacity building, network building and networking and effective communication (IAB, 2018).

The ten leadership competencies were measured based on the Competency Analytical Rubric, which consisted of ten competencies measured throughout the participants taking the NPQEL course. The ten competencies are a breakdown of the four Competency Domains, namely (i) visionary, (ii) leading change (iii) organizational excellence and (iv) skills. Assessment of participants is made to measure the competence of each individual with reference to the definition of competency set out in Table 1 Competency Dictionary. 


\begin{tabular}{|c|c|c|c|c|c|c|c|c|c|c|}
\hline 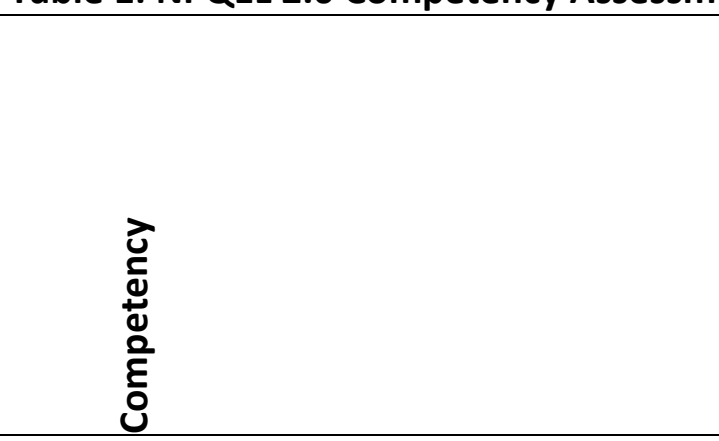 & 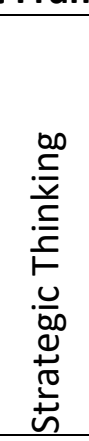 & 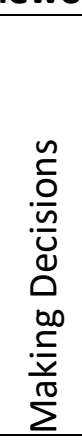 & 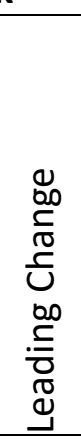 & 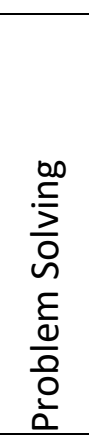 & 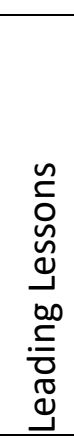 & 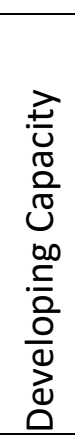 & 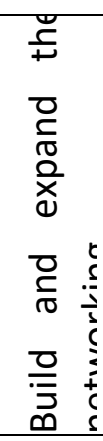 & 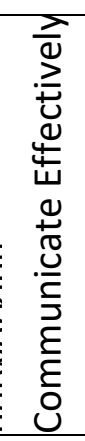 & 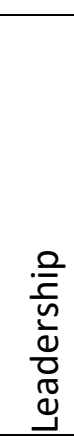 & 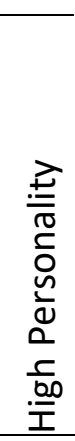 \\
\hline Assessment Activity & \multicolumn{10}{|c|}{ Competency Assessment } \\
\hline Executive Presentation 1 & $\mathrm{~V}$ & $\mathrm{~V}$ & $\mathrm{~V}$ & & & & & & $\mathrm{~V}$ & \\
\hline Executive Presentation 2 & $\mathrm{~V}$ & $\sqrt{ }$ & $\sqrt{ }$ & $\mathrm{V}$ & & & & & & \\
\hline Executive Presentation 3 & & & $\sqrt{ }$ & $\sqrt{ }$ & $\sqrt{ }$ & $\sqrt{ }$ & & & & \\
\hline Executive Presentation 4 & $\mathrm{~V}$ & & & $\mathrm{~V}$ & $\mathrm{~V}$ & $\sqrt{ }$ & & & & \\
\hline Executive Presentation 5 & & $\sqrt{ }$ & & $\mathrm{V}$ & & & $\mathrm{V}$ & $\mathrm{V}$ & & \\
\hline TAL Assessment Activities & Com & pete & cy As & sessn & hent & & & & & \\
\hline Protocol and Etiquette & & & & & & & & $\sqrt{ }$ & $\mathrm{V}$ & $\mathrm{V}$ \\
\hline Apprenticeship 1 & $\mathrm{~V}$ & $\sqrt{ }$ & & & & & & $\sqrt{ }$ & & $\mathrm{V}$ \\
\hline Apprenticeship 2 & $\sqrt{ }$ & $\mathrm{V}$ & $\mathrm{V}$ & $\mathrm{V}$ & $\mathrm{V}$ & $\sqrt{ }$ & $\mathrm{V}$ & $\sqrt{ }$ & $\mathrm{V}$ & $\mathrm{V}$ \\
\hline TAK Assessment Activities & \multicolumn{10}{|c|}{ Competency Assessment } \\
\hline Corporate Intelligence & & $\mathrm{v}$ & & $\mathrm{V}$ & & & $\mathrm{V}$ & $\sqrt{ }$ & & \\
\hline Benchmarking Visit to Private Institutions & & & & & & & & $\sqrt{ }$ & & $\mathrm{V}$ \\
\hline Talk Leadership Through Books & & & & & & & & $\sqrt{ }$ & $\mathrm{V}$ & $\mathrm{V}$ \\
\hline Total Competency Focus & 5 & 6 & 4 & 6 & 3 & 3 & 3 & 7 & 4 & 5 \\
\hline
\end{tabular}

Source: Institute Baki (2018)

Based on the table, each competency is measured in five levels consisting of (i) visionary, (ii) leading change, (iii) leading learning, (iv) developing Capacity and (v) building networks and networks. Each level is stated hierarchically according to a theme that has its own description along with illustrations to guide the implementation of competency-based assessment. Competency-based assessment refers to the NPQEL 2.0 Competency Assessment Framework according to the assessment activities as shown in Table 2. 
INTERNATIONAL JOURNAL OF ACADEMIC RESEARCH IN PROGRESSIVE EDUCATION AND

DEVELOPMENT

Vol. 10, No. 4, 2021, E-ISSN: 2226-6348 @ 2021 HRMARS

Table Error! No text of specified style in document.: Executive Presentation

\begin{tabular}{|c|c|c|}
\hline $\begin{array}{l}\text { Executive Presentation } \\
\text { Theme }\end{array}$ & Domain Competency & Competency Assessed \\
\hline Insightful & $\begin{array}{l}\text { - Insightful } \\
\text { - Leading Change } \\
\text { - Personality } \\
\end{array}$ & $\begin{array}{ll}- & \text { Strategic Thinking } \\
\text { - } & \text { Making decisions } \\
\text { - } & \text { Leadership } \\
\end{array}$ \\
\hline Leading Change & $\begin{array}{l}\text { - Insightful } \\
\text { - Leading Change }\end{array}$ & $\begin{array}{l}\text { Strategic Thinking } \\
\text { Making decisions } \\
\text { Lead Change } \\
\text { Problem Solving }\end{array}$ \\
\hline Leading Lessons & $\begin{array}{l}\text { - Leading Change } \\
\text { - Excellent Organization }\end{array}$ & $\begin{array}{ll}- & \text { Lead Change } \\
\text { - } & \text { Troubleshooting } \\
\text { - } & \text { Leading Learning } \\
\text { - } & \text { Capacity Building } \\
\end{array}$ \\
\hline Developing Capacity & $\begin{array}{l}\text { - Insightful } \\
\text { - Leading Change } \\
\text { - Excellent Organization }\end{array}$ & $\begin{array}{ll}- & \text { Strategic Thinking } \\
\text { - } & \text { Problem Solving } \\
\text { - } & \text { Leading Learning } \\
\text { - } & \text { Capacity Building } \\
\end{array}$ \\
\hline Build a Network & $\begin{array}{l}\text { - Leading Change } \\
\text { - Personality }\end{array}$ & $\begin{array}{l}\text { - } \quad \text { Making decisions } \\
\text { - } \quad \text { Problem Solving } \\
\text { - } \quad \text { Build and expand the } \\
\text { networking } \\
\text { - } \quad \text { Communicate } \\
\text { Effectively }\end{array}$ \\
\hline
\end{tabular}

Source: Institute Baki (2018)

Each participant has the opportunity to be assessed at least three times for the ten competencies through the assessment component. Only the highest achievement from a number of assessments performed on each competency will be taken to determine the Competency Level achieved. NPQEL participants must meet not less than the Competency Standard at Level 4 of the ten competencies assessed, in order to qualify for the following certificates:

i. Diploma in Educational Management and Leadership

ii. National Principalship Professional Qualification Certificate.

Ultimately, based on the chronology of the development of leadership competencies in Malaysia clearly shows that the leadership competencies of principals are always given serious attention and continuous improvement in line with the demands and challenges in the current world of education. According to Owens (2001) school leaders should have leadership competencies in the process of translating leadership theories and practices of organizational development and progress in developing education. This in turn can help school leaders to face every challenge to realize the educational goals to be achieved. In the context of educational leadership in Malaysia, MOE is always committed in developing leadership competencies in schools regardless of the status and geographical position of leaders. The IAB has been fully mandated by the MOE in efforts to develop the competencies of school leaders with support from ministries, education departments and district education offices. 
DEVELOPMENT

Vol. 10, No. 4, 2021, E-ISSN: 2226-6348 @ 2021 HRMARS

\section{Leadership Competencies}

Leader competence is defined as the wisdom, experience, and ability of a leader in performing tasks effectively and systematically (Boyatzis, 2011; Gentry et al., 2013). Robinson (2006) explained that the main thrust of an educational institution is the existence of a school leader who has the competence and knowledge and skills in teaching and learning management. Cherif et al (2009) in their study have found that there are nine aspects of leadership knowledge and skills that need to be possessed and practiced by a leader in school. The nine aspects are related to the knowledge and skills that cover the following i) management; ii) administration; iii) professionalism; iii) education; iv) interpersonal; v) external relations; vi) research and training; vii) supervision and evaluation; viii) self-development; and ix) finance. In this regard, Bush (2008) also stressed that a leader in a school should have personality traits and values in education. Whereas, Robinson (2006); Cherif et al (2009) also stressed the importance of knowledge leaders in managing a school.

McNair et al (2011) explained that school leaders should have the ability to learn the basic skills needed in leadership and have a high spirit to lead the organization. In fact, of all these stated characteristics are closely related to the competencies of leaders as already stated by Boyatzis (2011); Gentry et al (2013) that leadership competence refers to the behaviour of a leader who requires balance and intelligence from emotional, social and cognitive aspects. Jokinen (2005) classifies leadership competencies into four main components needed by a leader, namely the behaviour, personality, values and knowledge of a leader as a framework and guide to teach and study global leadership competencies.

The appointment of a competent primary school leader as required in an organization (Hollenbeck, 2006; Rothwell, 2010), required only those who are qualified and have their own competencies to be appointed to lead the school leadership. This should not be underestimated as it requires the future and development of a school. Therefore, in the context of education in Malaysia, school leaders, principals and principals who need to be appointed must pass the NPQEL and have the NPQEL qualification certificate as a mandatory condition to become a principal or headmaster (Ministry of Education Malaysia, 2013).

Accordingly, in order to form effective leadership then leadership development programs should be implemented as a platform towards improving the competencies of leaders in schools (Bush, 2008; Gentry et al., 2013). In addition, in the effort to develop leadership competencies, there are other approaches that can be used that is through guidance from experienced leaders in addition to following leadership development programs that emphasize the focus on real experiences experienced by leaders (Bush, 2008; DuBrin, 2010). In other words, leader competencies can be generated and developed by following a systematically planned leader development program (Bush, 2008). Such development programs need to be carefully planned and implemented in various ways such as using educational approaches, sharing of experiences and ongoing guidance from experienced and competent leaders (DuBrin, 2010).

Therefore, to realize the goals of national education, MOE needs leaders who are high performing and have the ability to face any current tribulations in the world of education. In line with that, school principals should be equipped with extensive knowledge in management and organizational leadership, have high commitment in the field of work, have the skills to 
manage and lead the school and always be prepared to face the demands of current education change very fast and complex (Esmaeil et al., 2013). This is because, the challenge of 21st century education demands school leaders who have high quality, ability and nature of accountability. This is because the quality of student excellence and school success is influenced by the leadership competencies of the principal.

A report released by IAB (2014) found that the leadership competencies of school leaders in Malaysia are still at a low level. These findings are in line with the Annual Report 2008, issued by the Board of Inspectors of Quality Assurance, (2009) on the level of leadership competencies of school leaders in Malaysia which is at a low level. In addition, referring to the IAB Report (2014) also, as of 2014, only 115 schools throughout Malaysia have been declared as High-Performance Schools and it only represents $1.13 \%$ of the total schools in Malaysia. These figures and percentages indicate that there is still a large performance gap between High Performance Schools and non-High-Performance Schools such as schools on the island. For this reason, this study was conducted to identify leadership competencies and implementation practices by school principals on the island in the state of Sabah.

\section{Study Method \\ Research Design}

In qualitative research, there are many study designs that can be used and each study design is different in terms of discipline, ideology and political influence (Bodgan \& Biklen, 2003). According to Punch (2001) the selection of appropriate study design can be done according to the four main principles of a research, namely:

i. Strategies that involve the purpose or approach of conducting research so that research questions can be answered

ii. Conceptual framework showing the correlation between one variable with another variable

iii. Research targets and goals

iv. Equipment and procedures to be used to collect and analyse empirical material

Based on these four main bases, the researcher has chosen the type of case study research as the research strategy. The selection of this research design is related to the purpose and approach of the study, the relationship of the conceptual framework between one variable and another, the research goals and objectives, equipment and procedures used for the process of collecting and analysing data (Creswell, 2014; Punch, 2001).

The research design for this study is in the form of exploration where the researcher will explore and deepen the leadership practices of principals in the management and leadership of schools on the island. Researchers construct a holistic picture, analyse actions and words, report in detail and in depth for each participant's views and conduct exploratory research in a natural "setting" (Creswell, 2014). According to Creswell (2014), qualitative design is inductive. This is because research is about generating ideas. The proposed design is continuous (up front) but open and expanding, not rigid and fixed to explore. In addition, the researcher himself will be a research instrument to collect data (Creswell, 2014; Stake, 2010) through interviews.

In conducting this study, the researcher examines the overall leadership practices of principals related to leadership competencies in the management of school organizations. Therefore, 
qualitative research is an appropriate research method because the researcher does not make any assumptions about the data findings that will be obtained. This is in line with qualitative research which is indeed characterized by exploration, discovery and interpretation rather than testing hypotheses as quantitative studies (Creswell, 2014; Stake, 2010).

\section{Case Studies}

According to Stake (2010) case study is a dominant idea and can change according to the suitability of an activity to explain a phenomenon and event. In the context of this study, the researcher plays a very important role to be in the field for the purpose of obtaining study data and find deeper answers about the case phenomena studied. This is because case studies are the main framework for conducting qualitative research (Stake, 2010) and allow researchers to observe and examine an event that occurs in the real environment and explore a complex social phenomenon (Creswell, 2014; Merriam, 2009)

To enable researchers to make accurate research, deepen an understanding and interpret data and obtain more in-depth information in accordance with the scope of the study on the leadership competencies of school principals on the island in the form of in-depth exploration. be required. The researcher used a case study approach to get answers for each research question. Thus, the researcher refers to the 'how' and 'how far' questions as suggested (Stake, 2010; Yin, 2011) to gain understanding and obtain data in a broader and deeper scope.

The case study approach in qualitative research is to facilitate the researcher to obtain the final data and describe the case in a focused and detailed and comprehensive in accordance with the phenomena, programs and activities in the actual context (Stake, 2010). Researchers are confident that the case study research approach can provide rich and in-depth information that is usually not available from another research (Lebar, 2014). Thus, based on the case study approach, the researcher believes that each data obtained will provide extensive and in-depth information and be able to provide real phenomena on the study issues. In fact, researchers believe that case studies are able to provide meaningful meaning and concrete answers to every research question related to the leadership competencies of school principals on the island as well as find in-depth and sufficient evidence.

\section{Data Analysis}

The findings of the study can take the form of structured descriptive statements, themes or categories that cross the data in the form of models and theories that describe the data. Each research method that is interview, observation and document analysis will go through a different analysis process at each stage so that the data obtained that is raw data can provide the information needed in the study.

In this study, researchers conducted a data analysis process as suggested by Lincoln and Guba (1985). The interview data and document analysis obtained will go through a simultaneous process and if during the data analysis process the researcher feels there is still a lack of data then the researcher will go back to the field of study. Researchers will continue to conduct interviews and document analysis until they reach saturation levels. The data obtained in qualitative research is often too much and comes from a variety of sources as well as various forms. The data collection process will not end even if the analysis process has begun. This happens continuously because less information will continue to be improved until new data 
emerges that no longer need improvement then the data collection process will be stopped. The process of data analysis is done continuously and in stages.

At the initial stage, all the data that has been collected by the researcher whether in the form of voice recording, observation and document analysis will go through the transcription process. Researchers will use computer software as a way to categorize and classify data findings systematically for coding purposes. Researchers will use ATLAS.ti 8. software for the purpose of data analysis. After that, the researchers combined the same data based on the codes that had been identified. Thus, the researcher reads the transcript and the information obtained repeatedly to identify the code or theme that emerges. After that, the researcher processes and reorganizes the code question to answer the focus of the study. Figure 1 shows the process of analyzing interview data using ATLAS.ti 8 software.

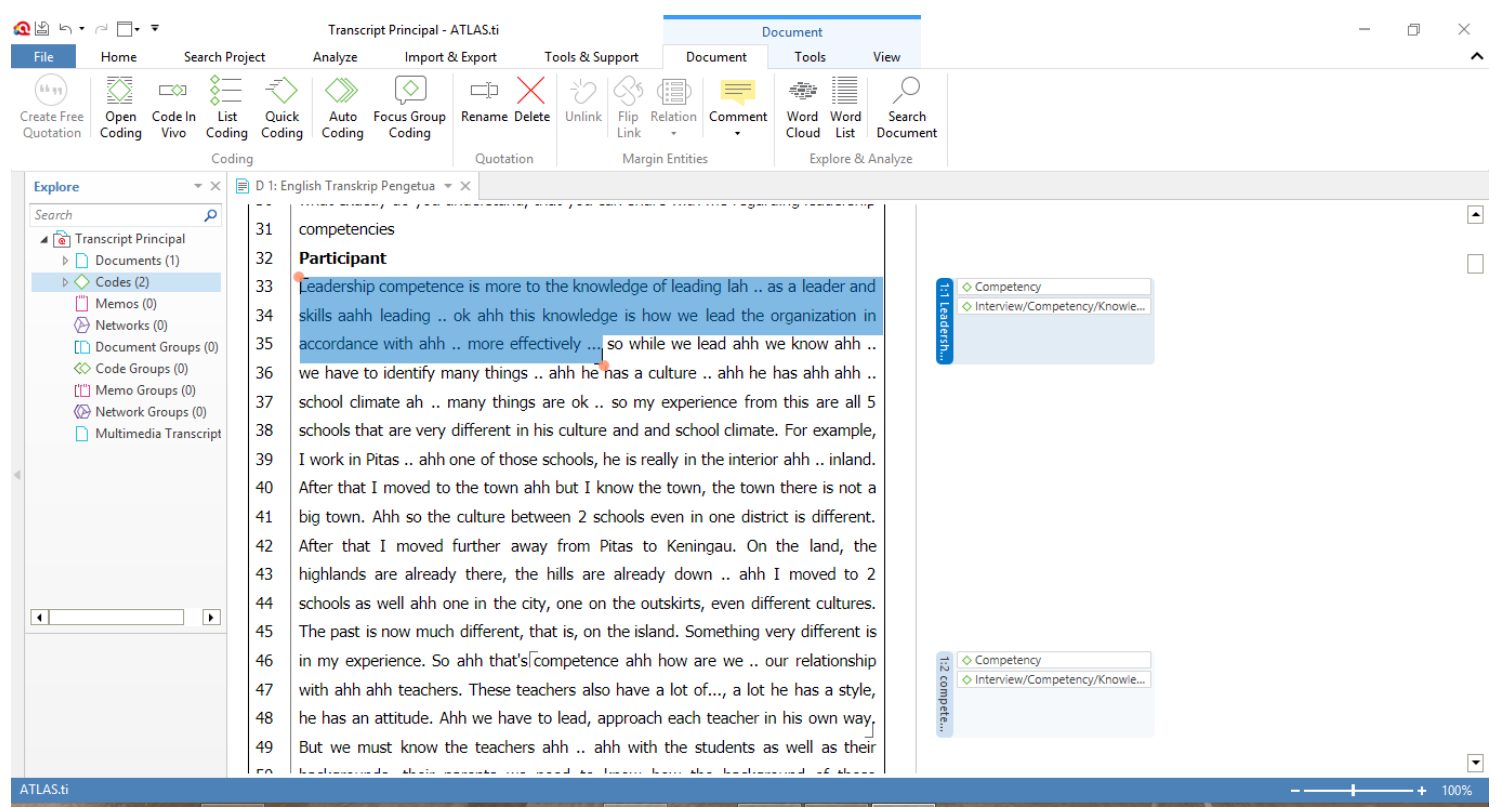

Figure 1: Data analysis using ATLAS.ti 8 software

In the early stages of the data collection process, data management is done by compiling the translated data in the form of transcripts for interview data, observations and document analysis data. After that, the transcript is analyzed to form the code. The codes will then be grouped into appropriate categories according to the similarity characteristics of the codes (Saldana, 2016). The next process is to classify these categories into theme groups based on the similarity characteristics of the categories that have been formed. The themes formed are based on themes that arise from previous studies. The final process in the data collection method for this study is, make a report based on the themes that arise to answer the research questions. Overall, the data analysis procedure in this study is based on Stake (2010) which was built by the researcher in the form of diagrams to formulate the data related to the leadership competencies of school principals on the island so that it can be easily understood throughout the data analysis. Figure 2 shows the data analysis procedure in this study. 


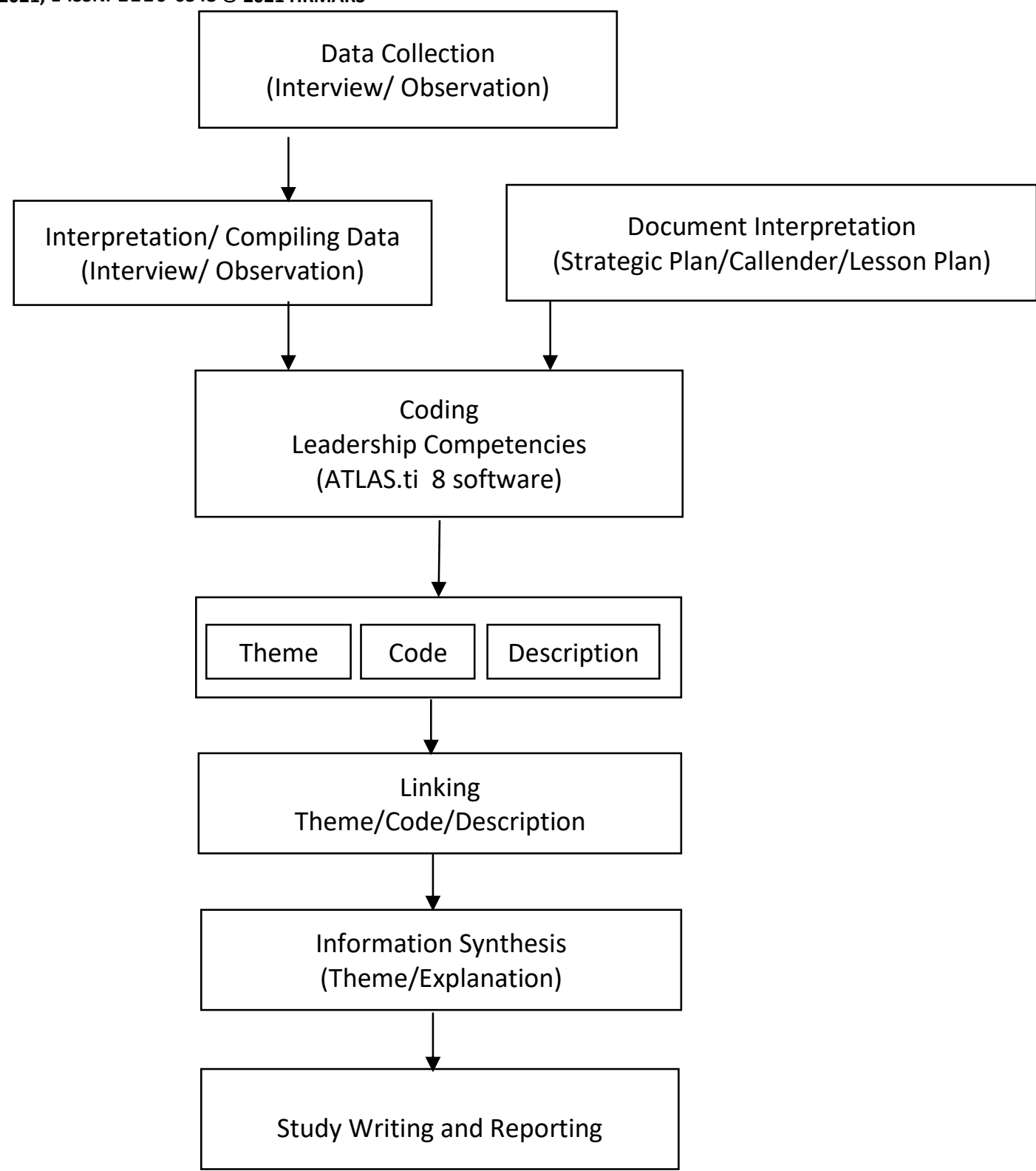

Figure 2: Data Analysis Procedure

Source: Stake (2010)

\section{Triangulation}

In the context of this study, the researcher uses the method of triangulation between data that is through interview data with study participants, observations and documents to ensure the data obtained has credibility. To ensure that the data has transferability, the researcher makes a detailed description of the events and individuals studied to gain an in-depth understanding of the situation to be studied. In addition, the researcher records all the data in electronic form to enable the study data to have reliability, while the verification audit process of the data obtained will be done to ensure that this study has validation or objectivity. Researchers will focus on triangulation of interview data through interviews on principals, senior curriculum assistants and subject teachers focusing on principal leadership competencies. 


\section{DEVELOPMENT}

Vol. 10, No. 4, 2021, E-ISSN: 2226-6348 @ 2021 HRMARS

While the proposed triangulation of document analysis involves school management documents especially those related to principal leadership such as strategic planning plan as additional data of the study. While the triangulation of the observed data is through the behavior of the principal in the daily activities of the school such as assemblies, holding meetings and performance dialogues. This data triangulation is done by connecting and merging the data of interviews, observations and documents to obtain data alignment. Pang and Lajium (2014) emphasized this is important because data triangulation is a comparison of quality and validation of information from various sources. Creswell (2014) and Creswell and Miller (2000) also stressed that this process is very important to strengthen and validate the evidence of study findings obtained from study participants. The triangulation of data between interviews, observations and document analysis is shown as in Figure 3.

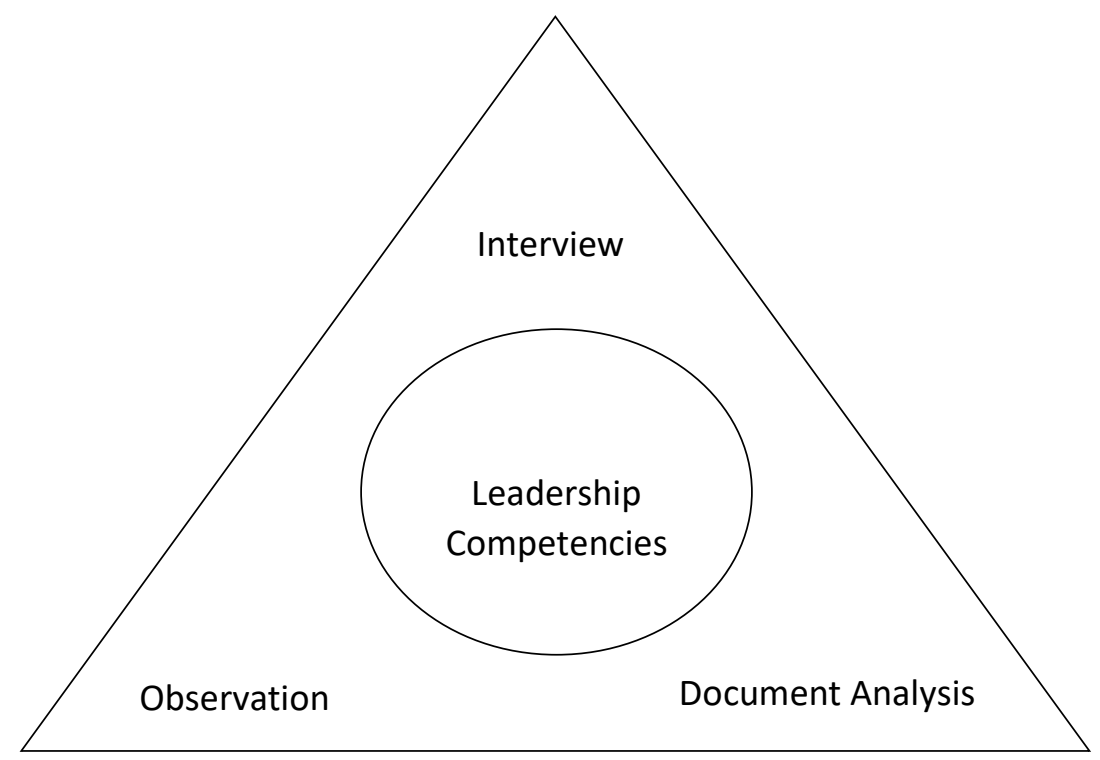

Figure Error! No text of specified style in document. : Triangulation between interviews, observations, and document analysis

\section{Findings}

\section{Knowledge}

The results of the study through interviews with the principal as the main participant of the study stressed that knowledge refers to the knowledge possessed by a principal in leading the organization to be more effective.

"...leadership competence is more to the knowledge of leading. As a leader and ahh leadership skills... okey ahh... this knowledge is how we lead the organization in accordance with ahh ... more effectively..."

[SP/8 September 2020/IT_B:34-37].

Leadership competencies in terms of knowledge possessed by the principal is also recognized by the senior assistant curriculum that the principal has the knowledge in leading the school organization. Not only that, the subject teacher also stressed that the principal has knowledge from the aspect of discretion and personality related to leadership. 
"...a principal of several schools, I think that already shows that she has the experience, knowledge, skills to lead a school ahh organization..." [SA/8 September 2020/IT_B:51-53].

"...in terms of what he is talking about, she is knowledgeable and because she has a personality, the category is so high..."

(ST/8 September 2020/IT_B:44-46]

\section{Skill}

The findings of the study in terms of skills under leadership competencies indicate that leadership skills should be present in a school principal on the island. For example, communication skills as a skill in leadership competencies to create a good relationship between the leader and the person being led. This statement is acknowledged by the principal himself that a principal with leadership competencies should have communication skills in leadership.

"...that communication needs to be taken care of. If you reprimand ahh, don't be in front. Ahh that... that... even the negative we have a story not like the boys want to be angry If the boys 'you have this shirt like this, no'... ahh we said it, pat him on the shoulder or whatever. If it's a girl. If it's a man, it's the same we talk slowly..."

[SP/8 September 2020/IT_B:127-131].

In addition, in support of the principal's statement, the senior curriculum assistant and subject teacher acknowledged that the principal has communication skills and at the same time has skills in establishing relationships with teachers and students at the island school.

"...she has an open attitude. For her PK, her KB. We have ahh what good relationship with him says...and her communication is really effective because she is two-way communication... ahh... that means between us communicating interpersonal and intrapersonal with us..."

[SA/8 September 2020/IT_B:486-489].

"...her relationship with this teacher is really good... so you can meet him anytime hahah. Anytime not necessarily in her room, she said. In the canteen, when she walks, will she serve you..." [ST/8 September 2020/IT_B:82-84]

\section{Behaviour}

The findings of the study in the aspect of behavior under leadership competencies show that principals have an open attitude towards teachers. In fact, the principal never limits his relationship with the teachers, instead it is easier to approach and easy to talk to.

"...principals are always open with teachers, like teachers can at any time if they go to the office to meet the principal. A lot of this is her business, ask for signatures, ask for discussions, share ideas. Ahh the principal is always ahh open..."

[SP/8 September 2020/IT_B:110-113].

The principal's behavior is acknowledged by the senior curriculum assistant who insists that the principal has a humble attitude and can adapt to the environment on the island. In fact, he stressed that the principal really appreciates the teachers and students. This is one of the 
behaviors that is clearly present in the principal. In fact, according to the subject teacher, the principal has a pretty good attitude in approaching the teachers and students in the school. "...she is very humble because the way she talks, the way she acts...after being humble, she has elements like how to say ahh, she has elements like ahh thinking like a villager. That means he saw him say he used to go to school like this in this city, he did this and so did this school here I see the boys need to do something we want ahh appreciate the student, the teachers so he has a concept is ahh what do you appreciate in a suitable concept..." [SA/8 September 2020/IT_B:297-303].

"...the way he approaches the teacher, the students and also how she controls the teacher and so on is considered good..." [ST/8 September 2020/IT_B:43-44].

\section{Discussion}

In the face of a very drastic and unrestricted educational change, the leadership of the principal is one of the areas being affected. The current challenges of principals are very diverse and complex, demanding that leadership competencies be given serious emphasis as the main backbone in an effort to improve the effectiveness and efficiency of a school. As is the case with school principals on the island, leadership competencies become a necessity in helping principals lead school excellence with different aspects of challenges and backgrounds compared to schools on the mainland. The findings of the study prove that principals in island schools must have leadership competencies in leading school change as well as holding to enable more effective and systematic leadership sustainability.

In line with Global Leadership Competencies that divide competencies into behaviour, cognitive and attitude (Bueno \& Tubbs, 2004), the findings of this study also prove that aspects of knowledge, skills and behaviour of an island school principal will determine the excellence of school leadership on the island. This is in line with the findings of Tubbs and Schulz (2006) who classify leadership competencies into the knowledge, skills and abilities of a leader. That is, armed with leadership competencies in terms of knowledge, skills and behaviour of a school principal on the island can contribute to the development and progress of a school consistently and continuously.

The findings of this study are also consistent with the findings of Bass and Bass (2008) that leadership competencies are the characteristics needed to do something, in this study also proved that island school principals should have leadership competencies in order to mobilize administrative machinery involving all school people. In this regard, principals should build good relationships with teachers as the main implementing group of the curriculum. Thus, the demand for effective communication skills and open attitude in behaviour are important aspects that need to be owned by the principal in order to form an effective and complementary work team for the sake of becoming students and school excellence on the island.

Ultimately, this study has proven that leadership competence is the main foundation that is the backbone to more effective educational management, especially for school principals on the island. Citing the findings of McNair et al (2011) that in order to manage the school more effectively a principal must have leadership competencies. Therefore, in line with the findings of this study together with the findings of previous studies, it is undeniable that the 
DEVELOPMENT

Vol. 10, No. 4, 2021, E-ISSN: 2226-6348 @ 2021 HRMARS

development of principal leadership competencies regardless of location should be given comprehensive, detailed and systematic attention in order to meet the demands of current educational change.

\section{Conclusion}

Leadership competencies should be emphasized in an effort to produce more effective island school principal leadership. IAB's efforts as a school leadership training centre in Malaysia need to be given attention and if necessary, every aspect should be reviewed in developing the competence of school leaders. The injection of NPQEL 2.0 elements with a new breath that is more organized and systematic in NPQEL is a drastic and wise step towards strengthening the level of competence of prospective principals. However, this effort cannot stop as far as the course alone but the IAB needs to be more committed in monitoring and developing the competencies of each NPQEL participant on an ongoing basis. This is very important, so that all aspects of competencies that have been applied throughout the participants in the NPQEL course continue to be practiced and used as an important guide in forming a more effective school management.

\section{References}

Bass, B. M., \& Bass, R. (2008). The bass handbook of leadership: Theory, Research and Managerial Applications (4th ed.). Free Press.

Bennis, W., \& Nanus, B. (1985). Leaders: The strategies for taking charge. Harper Collins.

Board of Inspectors and Quality Assurance. (2009). JNJK Annual Report Year 2008. Ministry of Education Malaysia.

Board of School Inspectors. (2004). Malaysian education quality standards - schools, standard statement. Ministry of Education Malaysia.

Bogdan, R., C., \& Biklen, S., K. (2003). Qualitative research in education: An introduction to theory and methods (4th ed.). Pearson.

Boyatzis, R. E. (2011). Managerial and leadership competencies: A behavioral approach to emotional, social and cognitive intelligence. Vision: The Journal of Business Perspective, 15(2), 91-100.

Bueno, C., \& Tubbs, S. L. (2004). Identifying global leadership competencies: An exploratory study. The Journal of American Academy of Business, 5(12),80-87.

Bush, T. (2007). Educational leadership and management: Theory, policy, and practice. South African Journal of Education, 27(3), 391-406.

Bush, T. (2008). Leadership and management development in education. Sage Publications Ltd.

Chen, H. C., \& Naquin, S. S. (2006). An integrative model of competency development, training design, assessment center, and multi-rater assessment. Advances in Developing Human Resources, 8(2), 265-282.

Cherif, A., Overbye, D., \& Stefurak, L. (2009). Developing a paradigm for academic leadership development. The Journal of Higher Education Management, 24(1), 16-34.

Creswell, J. W. (2014). Research design: Qualitative, quantitative, mixed methods approaches (4th ed.). Sage Publications Inc.

Creswell, J. W., \& Miller, D. L. (2000). Determining validity in qualitative and mixed methods approaches (4th ed.). Sage Publication Inc.

Drucker, P. (1992). Managing for the future: The 1990s and Beyond. Penguin.

DuBrin, A. J. (2010). Leadership: Research findings, practice and skills (7th ed.). South-Western. 
DEVELOPMENT

Vol. 10, No. 4, 2021, E-ISSN: 2226-6348 @ 2021 HRMARS

Eddy, P. L. (2013). Developing leaders: The role of competencies in rural community colleges. Community College Review, 41(1), 20-43.

Esmaeil, H., Rozita, Z., \& Amir, H. M. (2013). The relationship between emotional intelligence and personality features with job satisfaction status of male junior high school teachers in Islam shahr city. Journal of Educational and Management Studies, 3(3), 205-214.

Florida Department of Education (FDoE). (2008). Florida principal leadership standards. Retrieved from http://www.floridaschoolleaders.org.

Fullan, M. (2007). The jossey-bass reader on educational leadership (2nd ed.). John Wiley \& Sons Inc.

Fullan, M. (2015). The new meaning of educational change. Malaysian Institute of Translation \& Books.

Gentry, W. A., Eckert, R. H., Munusamy, V. P., Stawiski, S. A., \& Martin, J. L. (2013). The needs of participants in leadership development programs: a qualitative and quantitative cross-country investigation. Journal of Leadership \& Organizational Studies, 21(1), 83101.

Hallinger, P., \& Murphy, J. (1985). Assessing the instructional leadership behavior of principals. Elementary School Journal, 86(2), 217-248.

Hollenbeck, G. P., McCall, W.M. Jr., \& Silzer, R. F. (2006). Leadership competency models. The Leadership Quarterly, 17(4), 398-413.

Hussein Mahmood. (1989). A study of principals' perception of their competency needs in instructional leadership (Ph.D thesis). University of Michigan.

Indonesia National Education Strategic Plan (Renstra). (2009). The main policy of national education development. Ministry of National Education.

Institute Aminuddin Baki. (2006a). Malaysian school principal competency standards. Institute Aminuddin Baki.

Institute Aminuddin Baki. (2006b). Qualification guide to the national professional qualification program for principalship. Institute Aminuddin Baki.

Institute Aminuddin Baki. (2006c). Malaysian school principal competency standards. Institute Aminuddin Baki.

Institute Aminuddin Baki. (2010). The Institute Aminuddin Baki is stepping forward. Institute Aminuddin Baki.

Institute Aminuddin Baki. (2014). Leadership and management coaching and mentoring SIPartner+. Institute Aminuddin Baki.

Institute Aminuddin Baki. (2016).Training Programme. Institute Aminuddin Baki.

Institute Aminuddin Baki. (2018). National education leader professional qualification program assessment guide NPQEL. Institute Aminuddin Baki

Interstate School Leaders Licensure Consortium. (2008). Educational leadership policy standards. The National Policy Board for Educational Administration.

Jokinen, T. (2005). Global leadership competencies: A review and discussion. Journal of European Industrial Training, 29(3), 199-216.

Katz, R. L. (1993). Skills of an Effective Administrator. Harvard Business School Press. Retrieved from http://dev.sostreassoc.com.

Kotter, J. (1990). A force for change: How leadership differs from management. Free Press.

Leithwood, K., Louis, K. S., Anderson, S., \& Wahlsttom, K. (2004). Review of research: How leadership influences student learning. Wallace Foundation.

Lincoln, Y. S., \& Guba, E.G. (1985). Naturalistic inquiry. Sage Publication. 
Mazzeo, C. (2003). Improving teaching and learning by improving school leadership. National Governors Association Center for Best Practices. Educational Policy Studies Division.

McNair, D. E., Duree, C. A., \& Ebbers, L. (2011). If I knew then what I know now: Using the leadership competencies developed by the American Association of Community Colleges to prepare community college presidents. Community College Review, 39(1), 3-25.

Merriam, S. B. (2009). Qualitative research and case study apllications in education. JosseyBass Publication.

Ministry of Education Malaysia. (2006). National education policy. Government Printing.

Ministry of Education Malaysia. (2013). Malaysia's education development plan 2013-2025. Ministry of Education Malaysia.

Mohammed Sani Ibrahim, Ahmad Zabidi Abdul Razak \& Husaina Banu Kenayathulla. (2015). Malaysia's education development plan. University Malaya.

Lebar, O. (2014). Qualitative research introduction to theory and method. University Pendidikan Sultan Idris.

Owens, R. G. (2001). Organizational behavior in education: Instructional leadership and school reform (7th ed.). Retrieved from www.eric.ed.gov/ERICWebPortal.

Pang, V., \& Lajium, D. (2014). Assessment in education. University Malaysia Sabah.

Punch, K. F. (2001). Developing effective research proposal. Sage Publication.

Robinson, V. M. J. (2006). Putting education back into educational leadership. Leading and Managing, 12(1), 62-75.

Rothwell, W. J. (2010). Effective succession planning: Ensuring leadership continuity and building talent from within (4th ed.). American Management Association.

Saldana, J. (2016). The coding manual for qualitative researchers. Sage Publication.

Schein, E. H. (2004). Organizational culture and leadership (3rd ed.). Jossey Bass.

School Division. (2004). List of duties and responsibilities of the principal. Ministry of Education Malaysia.

Senin, A. (2008). Teacher professional development. Utusan Publications.

Spencer, L. M., \& Spencer, S.M. (1993). Competence work: Model for superior performance. John Willey \& Sons, Inc.

Stake, R. E. (2010). Qualitative research: studying how things work. The Guilforf Press.

Sudarwan, D. (2002). Educational innovation in an effort to improve the professionalism of the educational workforce. Pustaka Setia Publisher.

Sudrajat, A. (2008). Seventy percent of principals are incompetent. Retrieved from http://www.tempointeraktif.com.

Tubbs, S. L., \& Schulz, E. (2006). Exploring a taxonomy of global leadership competencies and meta-competencies. Journal of American Academy of Business, 8(2), 29-34.

Yin, R. K. (2011). Qualitative research from start to finish. The Guilford Press. 